\title{
ПРИЗНАКИ ДОГОВОРА СТРАХОВАНИЯ КАК ОТДЕЛЬНОГО ВИДА ОБЯЗАТЕЛЬСТВА
}

\section{SIGNS OF AN INSURANCE CONTRACT AS A SEPARATE TYPE OF OBLIGATION}

I. Telibekova

Summary. In the article, the insurance contract is considered from the point of view of a civil obligation. The author has studied the points of view of civilists about the main features of an insurance contract. The article considers the reflection in the current legislation of the signs of reality, consensuality, and compensability of the insurance contract. The opinions of scientists, both lawyers and economists, on the main trends in determining the signs of an insurance contract are given.

Keywords: insurance contract, obligation, policyholder, insurer, insured event, subject of the insurance contract, signs of the insurance contract, bilaterality, riskiness, reality, consensual, retribution, urgency.

\author{
Телибекова Ирина Мендигереевна \\ К.ю.н., Российская академия интеллектуальной \\ собственности, Москва \\ irina67.kz@mail.ru
}

Аннотация. В статье договор страхования рассмотрен с точки зрения гражданско-правового обязательства. Автором изучены точки зрения цивилистов об основных признаках договора страхования. Рассмотрено отражение в действующем законодательстве признаков реальности, консенсуальности, возмездности договора страхования. Приводятся мнения ученых, как юристов, так и экономистов, об основных тенденция в определении признаков договора страхования.

Ключевые слова: договор страхования, обязательство, страхователь, страховщик, страховой случай, предмет договора страхования, признаки договора страхования, двусторонность, рисковость, реальность, консенсуальность, возмездность, срочность.

существуют кредитор и должник, и последний всегда обязан совершить определенные действия в пользу кредитора. В цивилистической науке страхование всегда рассматривалось как разновидность гражданско-правового обязательства, возникающего на основе договора. И законодатель Российской Федерации (далее - РФ) включил сорок четыре статьи главы 48, содержащей нормы о договоре страхования (ст.ст. 927970), в Раздел IV «Отдельные виды обязательств» второй части Гражданского кодекса (далее - ГК) [5].

В гражданском праве все договоры подразделяются в зависимости от разных оснований на одно- и двусторонние, реальные и консенсуальные, возмездные и безвозмездные, срочные и бессрочные и т.д. Рассмотрим признак реальности. Так, сторонниками реальности договора страхования были К.А. Граве, Л.А. Лунц, О.С. Иоффе [6, С. 55; 7, С. 735]. Такого же взгляда придерживается и А.Г. Аракелян, который, обращая внимание на то, что ст. 957 ГК РФ является диспозитивной, все же подчеркивает: «договоры страхования по их экономической сущности следует относить к реальным видам договоров» [8, С. 57]. При этом указанные выше авторы упускают из виду то, для какой цели заключается этот договор. Некоторые ученые также, ссылаясь на исполнение обязанности страхователем по передаче имущества страховщику в виде уплаты страховой премии (взноса), и отмечая, что только после этого договор страхования вступает в силу, считают его реальным [9, 
C. 434]. Казахстанским законодателем признак реальности закреплен в самом определении договора страхования в ст. 803 ГК Республики Казахстан (далее - РК) [10].

Д.И. Мейер считал, что в основу отнесения договоров к реальным договорам лежит передача предмета договора [3]. Сразу отметим, что довод о реальности договоров, которые «считаются заключенными с момента передачи предмета договора», мы считаем необоснованным. Свою точку зрения мы обусловливаем тем, что реальное обязательство возникает после того, как передана вещь, а не «предмет договора». Этот довод имеет существенное значение, поскольку передача вещи не есть передача предмета договора. Это обстоятельство говорит о том, что здесь имеет место подмена тезиса, и она зачастую имеет место и в других научных трудах. Есть мнение ученых о том, что такие договоры, как договор хранения, договор перевозки считаются заключенными только с момента передачи предмета договора и именуются реальными (от лат. res - вещь) [11, С. 429]. Обязанности сторон в реальных договорах, согласно данному мнению, выполняются следующим образом: например, по договору хранения хранитель обязуется хранить переданную ему поклажедателем вещь, по договору перевозки перевозчик обязуется доставить вверенный ему отправителем груз в пункт назначения [Там же, С. 430]. То есть, как утверждают ученые, обязанности по договору возникают только после передачи вещи другой стороне.

В чем же с нашей точки зрения заключается подмена тезиса? Предметом договора, как и предметом любого гражданско-правового обязательства является не вещь, а обязанность должника по передачи вещи. Вещь, которая должна быть передана, является не предметом, а объектом заключаемого договора. В тоже время, данная вещь является предметом правоотношения. Это же ситуация касается предмета договора страхования и предмета страхования, смешение которых учеными бывает, к сожалению, очень часто. Так, К.Е. Турбина считает, что предметом договора страхования в страховании ответственности являются «имущественные интересы, связанные с возникновением обязанности страхователя компенсировать ущерб, причиненный его действиями имущественным интересам третьих лиц» [12, С. 128]. Но интерес никак не может быть предметом договора. Приведем высказывание М.И.Брагинского, который, сравнивает договоры страхования и хранения, а также их цели. При этом он пишет, что цель «для хранения - это сберечь вещь, в то время как для страхования - возместить убытки, причиненные гибелью или повреждением вещи. Кроме того, в договоре хранения обязанность сберечь вещь возлагается на сторону, предоставившую услугу (под услугой имеется ввиду соответственно сбережение), а при страховании, напротив, принятие мер по сбережению застрахованной вещи лежит на страхователе - стороне, которая обращается за услугами; соответственно в договоре хранения его предмет передается стороне, оказывающей услуги, в то время как при страховании никакой передачи имущества (автор рассуждает о передаче предмета страхования - прим. Т.И.) вообще нет» [13, С. 600-601]. Мы видим, что и здесь имеет место подмена тезиса, так как предметом договора страхования считают имущественные интересы.

Предмет договора страхования - это те действия страховщика, по поводу которых заключается договор и то, что ожидает получить кредитор взамен за определенную плату. А коль скоро из договора страхования возникает обязательство по оказанию услуги страхования, которая к тому же носит длящийся характер, и предметом договора страхования является действия страховщика по их оказанию, то договор страхования консенсуальный. Мы не можем относить договор страхования к реальным договорам. Причем, по нашему мнению, это относится ко всем договорам страхования в целом, поскольку цель данного договора сводится к страхованию, а не к уплате страховой премии.

По этому поводу мы считаем справедливыми доводы М.И. Брагинского. Он, прослеживая связь деления договоров страхования на одно- и двусторонние договоры с их реальностью или консенсуальностью, указывает, что «конструирование того или иного договора как реального или, напротив, консенсуального зависит от того, в чем выражается интерес каждой из сторон и какова соответственно ЦЕЛЬ договора» [Там же, С. 572]. Автор считает, что, если ЦЕЛЬ состоит в получении услуги, то указанное действие по оказанию услуги становится предметом договора. В этом случае законодателем договор формируется как консенсуальный. Причем М.И. Брагинский четко определяет свою позицию: «В остальных случаях, когда предметом договора служит совершение определенных действий по отношению к имуществу, законодатель выбирает модель реального договора» $[14$, С. 392].

Вторая группа цивилистов считает договор страхования консенсуальным договором. Например, Г.А. Жайлин отмечает, что «в легальном определении договор страхования формулируется в качестве консенсуального договора» [15, С. 238]. При этом автор относит договор страхования к консенсуальным договорам в силу того, что указанная в определении обязанность страховщика по осуществлению страховой выплаты, по его мнению, исполняется только в будущем, когда наступает при наступлении страхового случая. О консенсуальности договора страхования утверждают и В.Ю. Абра- 
мов, Е.М. Глушкова и другие, при этом уточняя, что договор вступает в силу с момента достижения соглашения по всем его существенным условиям, а уплата страховой премии будет производиться страхователем во исполнение ранее заключенного сторонами консенсуального договора страхования [16, С. 442; 17, С. 136]. М.И. Брагинский указывает, что если «страхователь, как это характерно для реального действия страхования, к моменту заключения договора выплатил полностью всю сумму страховой премии, на его стороне не остается никаких обязанностей. А это означает, что двусторонним может быть лишь консенсуальный договор страхования» $[13$, С. 572]. Получается, что если страхователь уплатил страховую премию в качестве определенного вознаграждения за страховую услугу, которая носит длящийся характер, то договор страхования консенсуальный.

Более обоснованными нам представляются доводы П.В. Сокола, в соответствии с которыми «страховые взносы не являются той вещью, которые применительно к конструкции реального договоров должна передаваться как условие его заключения» [18, С. 46-47]. Автор, подчеркивая, что в договоре страхования предметом выступают не страховые взносы, а страховая услуга, отмечает: «Обязательство по уплате страховых взносов является не главным в страховом обязательстве, а дополнительным. По этим причинам договор страхования необходимо квалифицировать как консенсуальный договор» [Там же]. В части того, что в договоре страхования предметом выступает страховая услуга мы не можем согласиться, так как предметом здесь является не просто страховая услуга, а действия страховщика по их оказанию.

Есть ученые, в соответствии с мнением которых договор может быть как реальным, так и консенсуальным [19, С. 24]. Например, А.К. Борончиева пишет: «Гражданский кодекс Кыргызской Республики устанавливает презумпцию реальности договора страхования, однако же эта норма является диспозитивной» [20, С. 63]. А.И. Худяков указывает, что «страховой договор может иметь три модели: 1) реального договора, <...> 2) консенсуального договора $<\ldots>3$ ) договора, который может быть как консенсуальным, так и реальным» [21, С. 249]. Мы видим, что авторы заняли позицию законодателя, который в ст. 957 ГК РФ внес норму, согласно которой договор страхования, если в нем не предусмотрено иное, вступает в силу в момент уплаты страховой премии или первого ее взноса [5]. Эта норма является диспозитивной, и говорит о возможности как реального, так и консенсуального договора страхования.

Рассмотрим признак двусторонности договора страхования. Как правило, наличие встречных обязательств говорит о том, что у каждой стороны в договоре присутствуют взаимные права и обязанности [22, С. 9-10]. По поводу двусторонности страхового обязательства есть мнение о том, что «Страховое обязательство является двусторонним обязательством, то есть и страховщик, и страхователь одновременно выступают в роли и кредитора, и должника» [21, С. 37]. Действительно, по договору страхования и страховщик, и страхователь наделены и правами, и обязанностями. Законодатель, как российский, так и казахстанский, включают в договор ряд условий, которые являются обязательными, то есть существенные условия, без согласования которых он считается недействительным. Но Е.М. Глушкова, отрицает взаимосвязь признаков двусторонности с возмездностью, указывая при этом, что «Деление на односторонние и двусторонние договоры автономно от классификации на возмездные и безвозмездные» [23, С. 136]. Мы полагаем, что все же есть взаимосвязь встречной обязанности страхователя по уплате страховой премии с возмездностью услуги страхования. И российский законодатель подтверждает нашу точку зрения, указывая в ч. 1 ст. 954 ГК РФ, что «Под страховой премией понимается плата за страхование, которую страхователь (выгодоприобретатель) обязан уплатить страховщику в порядке и в сроки, которые установлены договором страхования» [5]. По этому поводу примечательна точка зрения А.И. Худякова: «страховые премии являются платой страхователя за товар» [21, С. 8]. При этом в качестве товара указана страховая услуга. Здесь позиция автора о том, что связка «страховая премия как форма платы за страхование - страховая выплата как форма страховой защиты» характеризует материальное страховое отношение в качестве возмездного» представляется нам безошибочной [Там же, С. 83].

В качестве еще одного довода в пользу того, что при заключении договора страхования уплата страховой премии не ставится во главу угла, можно привести содержание ст. 942 ГК РФ о существенных условиях договора страхования. Так, в качестве существенного условия, без которого договор не может быть заключен, законодатель не указал условие об уплате страховых премий. Кроме того, и в ст. 939 ГК РФ в обязанности страхователя уплата страховой премии как основание заключения договора страхования не включена [5]. Мы видим последовательность российского законодателя по вопросу консенсуальности договора страхования, поскольку им, во-первых, договор страхования внесен в раздел отдельных видов обязательств, и в этом договоре уплата страховой премии не указана в качестве существенного условия договора страхования. В-вторых, уплата страховой премии не установлена в качестве первостепенной обязанности страхователя при выполнении им обязанностей по договору страхования. Однако эта норма говорит о том, что законодатель РФ 
по поводу реальности или консенсуальности договора страхования оставляет выбор за сторонами договора, в то же время включая в ГК положения, прямо указывающие на консенсуальность договора страхования.

Такая же позиция и у казахстанского законодателя (ч. 1 ст. 827 ГК РК). Однако в п. 1 ч. 1 ст. 831 ГК РК уплату страховой премии определена как первостепенная обязанность страхователя для заключения договора страхования [10]. И, как правило, в силу этого и согласно трактованию буквы закона договор страхования относится казахстанскими учеными к реальным договорам. При этом они ссылаются на то, что без получения страховщиком платы за осуществление страховой услуги договор не может быть заключен. Многие не берут во внимание, что должником в страховом обязательстве все же является страховщик, и забывают о предмете страхового обязательства. Здесь можно привести точку зрения А.А. Даркова, который отмечает, что «Обязательство в самом широком смысле представляет собой моральный или юридический долг» [24, С. 53]. Ведь, несмотря на то что договор страхования является двусторонним, страховую услугу осуществляет страховщик, и эта услуга носит длящийся характер. В этой связи мы полагаем, что возмездность договора страхования означает встречное предоставление страхователя за исполнение обязанностей должником страхового обязательства в виде оказания услуги страхования.

Договор страхования является срочным договором, поскольку в договоре стороны всегда определяют временные границы, в течение которого действует услуга страхования, оказываемая страховщиком. Но страховая услуга не представляется одномоментно сразу же после уплаты страховой премии, подписания сторонами договора страхования и его заключения. Практика страхования показывает, что все договоры начинают действовать только на следующий день после его заключения. То есть, несмотря на уплату страховой премии страхователем, страховая услуга, оказываемая страховщиком, «включается» через сутки. Срок действия договора страхования начинает течь через 24 (двадцать четыре) часа после достижения соглашения между сторонами страхового обязательства.

Цивилистами выделен еще один из нескольких признаков, характерных для договора страхования, такой как рисковость, что существенно его отличает от всех других видов гражданско-правовых договоров. Некоторые ученые полагают, что этот признак характерен только договорам страхования. Д.И. Мейер, напротив, считал, что риск и страх есть у каждого из сторон обязательства: «Каждое обязательство сопровождается риском или страхом. Действие, составляющее предмет обязательства и представляющееся при заключении его возможным, может оказаться впоследствии невозможным» [3]. Ряд ученых, связывая рисковость с наличием или отсутствием признаков страхового случая (вредоносность, вероятность, случайность, нежелательность), делят все договоры страхования на рисковые и безрисковые [19, С. 11; 21, С. 223; 25, С. 64]. При этом в качестве безрискового договора страхования указывают договора на дожитие. В то же время в науке имеется другая точка зрения, согласно которой «страховой случай может произойти, но может и не произойти» [26, С. 521]. И эта точка зрения нам представляется наиболее верной. То есть, если это вредоносный страховой случай, несущий негативные последствия, то возможна «случайность его наступления», которая нежелательна для страхователя, застрахованного. Если это невредоносный страховой случай, наступление которого не приносит страхователю каких-либо негативных последствий, то даже при его предсказуемости, ожидаемости и закономерности возможна «случайность его ненаступления». По этому поводу справедливо замечание А.К. Шихова о том, что при страховании «возможность ненаступления каких-либо ожидаемых событий <...> известное событие может не произойти в определенный период времени» [27, С. 27]. Получается, что предсказуемое событие может не наступить по случайному стечению обстоятельств. Действительно, страхование, как личное, так и имущественное, всегда зависит от объективных и субъективных обстоятельств, от субъективной и объективной вероятности. Примечательна точка зрения А.Г. Гойхбарга, который считал, что «при лихорадочном темпе нашей жизни, при массе грозящих на каждом шагу неожиданностей, неожиданностей $<\ldots>$ никто не уверен в завтрашнем дне, никто не ведает, что станется с ним самим, с его имуществом, с его близкими» [28, С. 772]. Это мнение А.Г. Гойхбарга, которое и на сегодняшний день остаётся актуальным, подтверждает наши доводы о том, что рисковость договора страхования следует рассматривать с другого ракурса.

Мы считаем, что все договоры страхования являются рисковыми в силу того, что его стороны, заключая договор, не знают, наступит страховой случай или нет вне зависимости от того, является ли он вредоносным или невредоносным. В этом, по нашему мнению, и заключается рисковость любого договора страхования. Если страховой случай предвиден, невредоносен и позитивен, то его наступление ожидаемо, страхователь желает его наступления. Но нет вероятности, что страховой случай обязательно наступит. В этом и заключается риск для страховщика и для страхователя. Именно поэтому последний и прибегает к услугам страхования. Если при заключении договора страхования не предполагается риски наступления или ненаступления страхового случая, который является особенностью данного вида обязательства, то незачем заключать этот дого- 
вор, так как осуществление страхования без какого-либо риска не будет иметь смысла, который, собственно, и заложен в его основу. Это, в свою очередь означает, что существование страхования без риска (безрискового страхования) не обосновано.
Изложенные выше научные воззрения и доводы показывают, что на протяжение нескольких столетий вопросы о признаках договора страхования остаются дискуссионными, а сам договор страхования занимает в цивилистической науке отдельное место.

\section{ЛИТЕРАТУРА}

1. Басин Ю.Г. Избранные труды по гражданскому праву. / Предисловие Сулейменов М.К., Ихсанов Е.У. / Сост. Сулейменов М.К. Серия «Классика казахстанской цивилистики». — Алматы: АЮ — ВШП «Әділет», НИИ частного права КазГЮУ, 2003.— 734 с.

2. Покровский Б.В. Избранные труды по гражданскому праву / Предисловие Сулейменов М.К., Алиханова Г.А., Ихсанов Е.У. / Сост. Сулейменов М.К. Серия «Классика казахстанской цивилистики».—- Алматы: НИИ частного права КазГЮУ, 2003. - 404 с.

3. Мейер Д.И. Русское гражданское право (в 2 ч.). По исправленному и дополненному 8-му изд., 1902. Изд. 3-е, испр. М.: «Статут», 2003.— 831 с. (Классика российской цивилистики.) URL: https://civil. consultant.ru/elib/books/45/page_55.html (Дата обращения: 08.08.2021 г.).

4. Шершеневич Г.Ф. Учебник русского гражданского права (по изд. 1907 г.). — Москва: Спарк, 1995. — 460 с.

5. Гражданский кодекс Российской Федерации (часть вторая) от 26.01.1996 г. 14-Ф3. - М.: Издательство «Проспект», 2021.

6. Граве К.А., Лунц Л.А. Страхование - М.: Госюриздат, 1960. - 176 с.

7. Иоффе 0.С. Обязательственное право. - М.: Юрид. лит., 1975.- 880 с.

8. Аракелян А.Г. Проблемы понятия и квалификации договора страхования в современном гражданском праве // Legal Concept. — 2009. — № 11.— C. 56-62.

9. К Комментарий к Гражданскому кодексу Казахской ССР / Под ред. Ю.Г. Басина, Р.С. Тузутдинова. — Алма-Ата: Казахстан, 1990. — 688 с.

10. Гражданский кодекс Республики Казахстан (особенная часть) от 01.07.1999 г. - Алматы: Юрист, 2021.

11. Гражданский Кодекс Республики Казахстан (Особенная часть). Комментарий. - Изд. 2-е, испр. и доп., с использованием судебной практики / Отв. ред.: М.К. Сулейменов, Ю.Г. Басин. — Алматы: Жеті жарғы, 2003.— 832 с.

12. Турбина К.Е. Тенденции развития мирового рынка страхования. - М.: Анкил, 2000. -320 c.

13. Брагинский М.И., Витрянский В.В. Договорное право. Книга третья: Договоры о выполнении работ и оказании услуг. - Изд. дополнительное, исправленное (4-й завод). — М.: «Статут», 2004.- 1055 с.

14. Брагинский М.И., Витрянский В.В. Договорное право. Книга первая: Общие положения: издание 2-е, завод 6-й (стереотипный).- М.: «Статут», 2003. - $848 \mathrm{c}$.

15. Жайлин Г.А. Гражданское право Республики Казахстан. Часть Особенная. — Алматы: Данекер, 2001. Т. 1. — 354 с.

16. Абрамов В.Ю. Страхование: теория и практика.-М.: Волтерс Клувер, 2007.— 504 с.

17. Глушкова Е.М. Теоретические основы понятия и применения договора страхования в современном российском праве // Гуманитарные, социально-экономические и общественные науки. - 2017.— № 3.— - . 135-137.

18. Сокол П.В. Понятие договора страхования по дореволюционному, советскому и российскому законодательству // Юридический вестник Самарского университета. - 2016. - № 2.- С. 43-49.

19. Гекко М.Н. Договор страхования по законодательству Республики Казахстан: автореф. на соиск. уч. степ. к.ю.н.: 12.00.03. 一 Алматы, 2005.— 33 с.

20. Борончиева А.К. Юридическая природа договора страхования в Кыргызской Республике // Крымский научный вестник. - 2016. — № 2. — C. 61-71.

21. Худяков И.А., Демидова Г.С., Худяков А.А. Основы страхового права: Учебное пособие.- Челябинск: ЮУрГУ, 2004. - 432 с.

22. Белых В.С., Кривошеев И.В. «Договор страхования: понятие, форма и содержание» // Юридический вестник.— 1999 г.— № 9.— С. 9-10.

23. Глушкова Е.М. Теоретические основы понятия и применения договора страхования в современном российском праве // Гуманитарные, социально-экономические и общественные науки. - 2017.— № 3.- С. 135-137.

24. Дарков А.А. Обязательства в современном гражданском праве российской Федерации // Вестник Московского университета МВД России. - 2019. № 3.- - C. 53-56.

25. Шинкаренко И.Э. Страхование ответственности. Справочник. - Москва: Финансы и статистика, 1999. — 352 с.

26. Гражданское право: Учебник для вузов (академический курс). / Отв. ред.: М.К. Сулейменов, Ю.Г. Басин. НИИ частного права КазГЮУ.— Алматы, 2002. T. II. -624 c.

27. Шихов А.К. Страхование: Учебное пособие для вузов. - М.: ЮНИТИ-ДАНА, 2000. - 431 с.

28. Гойхбарг А.Г. Единое понятие страхового договора. // Право. — 1914.— № 10.— C. 761-772. 